\section{Metastatic malignant melanoma of the small intestine: capsule endoscopic appearance}

Capsule enteroscopy (CE) can identify primary [1] and metastatic intestinal melanoma, as previously described [2] and illustrated with surgical and histological verification [3]. However, capsule enteroscopic identification of the characteristic coal-black appearance of malignant melanoma has not been described previously in intestinal tumors.

A 56-year-old man receiving dendritic cell-based therapy for metastatic malignant melanoma presented with anemia and black stools. Abdominal computer tomography suggested peritoneal carcinomatosis. There were no clinical or radiological signs of intestinal obstruction. Gastroscopy and colonoscopy were normal. CE revealed a localized area with whitish tissue and characteristic coalblack, sharply demarcated circular areas, consistent with metastatic melanoma. This area was located in the ileum, centrally in the abdomen, after 6 hours 19 minutes ( Figure 1, Video 1 ). Because of the disseminated disease and the absence of obstructive symptoms, the dendritic cell-based therapy was continued without surgical intervention. The patient passed away 2 months later.

Endoscopy_UCTN_Code_CCL_1AC_2AC

\section{J. Smedegaard, S. Adamsen}

Department of Gastrointestinal Surgery, Copenhagen University Hospital Herlev, Herlev, Denmark

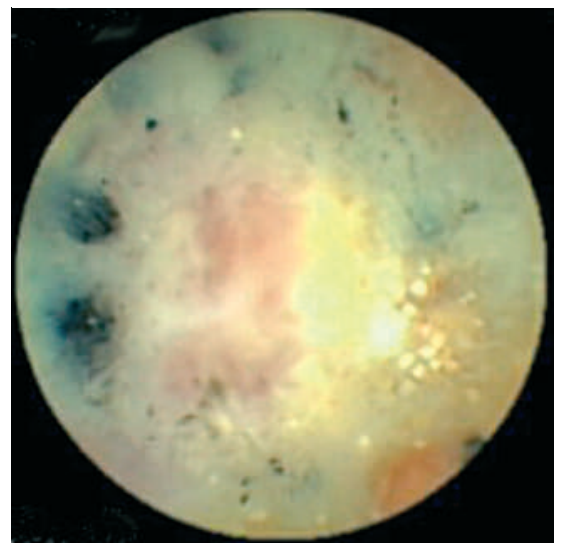

Figure 1 Capsule endoscopic appearance of a metastatic malignant melanoma in the small intestine.

\section{Video 1}

Capsule endoscopic appearance of a metastatic malignant melanoma in the small intestine.

online content including video sequences viewable at:

www.thieme-connect.de/ejournals/abstract/ endoscopy/doi/10.1055/s-2007-966319

\section{References}

1 Kruger S, Noack F, Blochle C, Feller AC. Primary malignant melanoma of the small bowel: a case report and review of the literature. Tumori 2005; 91: 73-76

2 Bailey AA, Debinsky HS, Appleyard MN et al. Diagnosis and outcome of small bowel tumors found by capsule endoscopy: a threecenter Australian experience. Am J Gastroenterol 2006; 101: 2237-2243

3 Lykke J, Hansen MB, Ovesen H, Meisner S. Capsule endoscopy detection of metastasis of a malignant melanoma in the small intestine. Ugeskr Læger 2006; 168: $3533-$ 3534
Bibliography

DOI $10.1055 / \mathrm{s}-2007-966319$

Endoscopy 2007; 39: E209

(c) Georg Thieme Verlag KG Stuttgart · New York . ISSN 0013-726X

\section{Corresponding author}

\section{S. Adamsen, MD}

Department of Gastrointestinal Surgery

Copenhagen University Hospital Herlev

75, Herlev Ringvej

DK-2730 Herlev

Denmark

Fax: +45-4488-4009

sven.adamsen@dadlnet.dk 